\title{
Near-seafloor magnetic signatures unveil serpentinization dynamics at ultramafic-hosted hydrothermal sites ${ }^{1}$
}

\author{
Florent Szitkar ${ }^{1}$ and Bramley J. Murton² \\ 1Japan Agency for Marine-Earth Science and Technology (Jamstec), 2-15, Natsushima-cho, \\ Yokosuka-city, Kanagawa 237-0061, Japan \\ ${ }^{2}$ National Oceanographic Centre, European Way, Southampton SO14 3ZH, UK
}

\begin{abstract}
A near-seafloor magnetic and bathymetric survey conducted by the autonomous underwater vehicle AutoSub 6000 over intermediatetemperature, ultramafic-hosted Von Damm Vent Field (Mid-Cayman spreading center, Caribbean Sea) revealed a moderate positive magnetic anomaly, in accordance with the magnetic response of other known ultramafic-hosted hydrothermal vent fields. However, compared with low-temperature ultramafic-hosted hydrothermal activity, the magnetic signature of this intermediate-temperature site indicates a slightly stronger magnetization contrast between the hydrothermal system and its host, but it remains considerably weaker than at high-temperature ultramafic-hosted hydrothermal vent fields. This observation highlights the nonlinear increase of magnetization production with temperature, as iron partitions into weakly magnetic brucite under $200^{\circ} \mathrm{C}$, but magnetite dominates above this temperature, leading to a sudden increase in the magnetic signature of a site. Our study is consistent with recent laboratory experiments and unveils the dynamics of the serpentinization reaction, enabling fine tuning of the magnetic technique for remotely locating hydrothermal systems. In addition to refining our understanding of the magnetic behavior of hydrothermal vent fields, these new results also reveal the orientation of the fluid pathway feeding the hydrothermal site and indicate the nonvertical structure of the complex network of fissures within the host rock and its associated tectonic feature-an oceanic core complex.
\end{abstract}

\section{INTRODUCTION}

Hydrothermal vents are the hot springs of the deep ocean floor, and active systems play a key role in the dissipation of Earth's internal heat and in the ocean chemical budget. Almost four decades after their first discovery (Corliss et al., 1979), large-scale seafloor exploration, including the use of underwater vehicles, has located over 350 active and inactive hydrothermal sites that are mostly hosted on a basaltic substratum. Along slow-spreading ridges, however, the combination of limited magma supply (Cannat, 1993), volcanic accretion, and tectonic dismemberment of the oceanic crust (Tucholke et al., 1998; Escartín et al., 2008) favors the development of long-lived detachment faults exposing mantle outcrops and oceanic core complexes (OCCs). These settings lead to a greater diversity of hydrothermal vent fields than at fast spreading ridges (Rona et al., 2010). Although the magnetic footprint of basalt-hosted hydrothermal systems is well constrained (e.g., Tivey et al., 1993; Honsho et al., 2013; Szitkar et al., 2014a), that of ultramafic-hosted hydrothermal sites (UMHSs) remains poorly understood. Two recent studies over highand low-temperature UMHSs, the Rainbow and Lost City vent fields (MidAtlantic Ridge), respectively (Szitkar et al., 2014b, 2017), have emphasized the relation between fluid temperature and amount of magnetite generated by serpentinization

\footnotetext{
${ }^{1}$ Post-print of: Szitkar, F., and Murton, B.J., 2018, Near-seafloor magnetic signatures unveil serpentinization dynamics at ultramafic-hosted hydrothermal sites: Geology, v. 46, p. 1-4, https://doi.org/10.1130/G45326.1
} 
reactions within the sites' stockwork zones or plumbing systems. Nevertheless, the precise evolution of magnetite production with temperature remains unknown. To address the knowledge gap between these two end-member UMHSs, we used high-resolution magnetic and bathymetric data collected over an intermediate-temperature UMHS, the Von Damm Vent Field (VDVF), at the Mid-Cayman spreading center, Caribbean Sea. The VDVF is hosted on an OCC exposing a mixture of ultramafic and gabbroic rocks (Connelly et al., 2012a). Our study revealed that the VDVF is consistently associated with a positive magnetic anomaly. It also suggests that magnetite production, i.e., the serpentinization dynamics, follows a nonlinear evolution when temperature increases, with a slow progression under $200^{\circ} \mathrm{C}$, followed by a dramatic increase in the production rate above this critical temperature. This makes the remote detection of hightemperature UMHSs using magnetic signatures easier. Moreover, the characteristics of the magnetic response at the VDVF suggest the presence of an inclined fluid pathway feeding the vent field, revealing the existence of a complex fault network within the host OCC structure.

\section{GEOLOGICAL CONTEXT}

The Mid-Cayman spreading center is a tectonically isolated, northsouth-oriented, 110-km-long, ultraslow-spreading ridge in the Caribbean Sea. Its full spreading rate is $2 \mathrm{~cm} / \mathrm{yr}$ (Ballard et al., 1979), and the axial valley depth ranges from 4500 to $6500 \mathrm{~m}$, making it the deepest spreading center in the world (ten Brink et al., 2002). At $18^{\circ} 30^{\prime} \mathrm{N}$, a prominent bathymetric anomaly rising up to a depth of $2100 \mathrm{~m}$ forms the western flank of the axial valley. This 3000-m-high massif, known as Mount Dent, has been identified as an OCC (Fig. 1A; Hayman et al., 2011). It is characterized by the typical dome-like structure of OCCs and exhibits spreading-parallel, eastwest-oriented corrugations. The OCC itself is composed of exposed upper-mantle ultramafic and lowercrust gabbroic rocks (Hayman et al., 2011). Not far from its summit, the active UMHS VDVF has recently been discovered at a depth of $2300 \mathrm{~m}$ (Connelly et al., 2012a), i.e., comparable to the depth of UMHS Rainbow (Fig. 1B). This UMHS sits $13 \mathrm{~km}$ west from the current spreading axis and consists of a single $\sim 50$-m-high mound, extending over an area of $200 \times 300 \mathrm{~m}$, and dominating the surrounding smooth slope of the OCC (Fig. 1B). Unlike the low-temperature Lost City vent field, which is characterized by massive carbonate structures venting high-pH fluids and a probable shallow heat source (Kelley et al., 2001), the VDVF is associated with a talc-dominated mineralogy and a deep heat source, as a result of the OCC fault network (Hodgkinson et al., 2015). The VDVF is actively venting fluids with a measured temperature of up to $215^{\circ} \mathrm{C}$, and fluid sampling on the site has revealed that iron concentrations within the fluids are lower than at Rainbow (Connelly et al., 2012a; Hodgkinson et al., 2015).

\section{METHODS}

During Cruise 44 of RRS James Cook in 2010, (Connelly et al, 2012b) high-resolution magnetic and bathymetric data were acquired by a threecomponent fluxgate magnetometer mounted on the autonomous underwater vehicle (AUV) Autosub 6000 along 70-m-apart, regularly spaced, parallel profiles. The AUV's altitude above the seafloor ranged from 20 to $160 \mathrm{~m}$, optimizing the magnetic detection of small-scale targets such as hydrothermal sites. As the magnetometer sensor was directly mounted to the AUV, the magnetic influence of the vehicle had to be derived and removed from the data (Isezaki, 1986; Honsho et al., 2009) to resolve the crustal magnetic anomalies (see the GSA Data Repository1).

Because of the inclination and declination of Earth's geomagnetic field, crustal magnetic anomalies are phase-shifted and need to be corrected for their location to relocate them above their sources within the crust. The data were first used to estimate the seafloor equivalent magnetization using the Bayesian inversion of Honsho et al. (2012). This magnetization 
distribution was then used to compute the reduced-to-the-pole (RTP) anomaly (Fig. 2; see the Data Repository).

\section{RESULTS AND DISCUSSION}

The positive magnetic anomaly observed over UMHSs results from several factors, including (1) an accumulation of strongly magnetized magnetite produced by serpentinization reactions within the hydrothermal plumbing and stockwork zones; (2) the dimensions of the hydrothermal system at depth, i.e., the volume of its deep parts; and (3) the presence of reducing hydrothermal fluids that prevent later oxidation of serpentinitehosted magnetite by contact with seawater (Szitkar et al., 2014b). In addition, it has also been shown that the amount of magnetite produced by serpentinization reactions is influenced by hydrothermal fluid temperature (Szitkar et al., 2017), in accordance with laboratory experiments (Klein et al., 2014). Indeed, high temperatures $\left(>200^{\circ} \mathrm{C}\right)$ favor iron partitioning into magnetite, whereas low temperatures preferentially partition it into less-magnetic brucite (Früh-Green et al., 1996, 2004; Klein et al., 2014). This latter case is likely to result in the formation of a limited amount of magnetite within the stockwork zones beneath UMHSs, and hence a weak positive magnetic anomaly (Szitkar et al., 2017).

UMHSs with different temperature regimes offer the opportunity to explore the amplitude of hydrothermal magnetite-produced magnetic anomalies. The Rainbow and Lost City UMHSs represent the two currently known ultramafic-hosted hydrothermal end members (venting fluid temperatures of $350^{\circ} \mathrm{C}$ and $92^{\circ} \mathrm{C}$, respectively); however, the exact evolution of magnetite production with temperature remains unclear, as the two examples are insufficient for precise constraints. At the VDVF, we considered two options: either the venting temperature has always been relatively stable, or it was initially higher and progressively decreased over time. In this latter case, precipitated sulfide should be abundant, but none has been observed, and deposits are largely dominated by talc and silica, which can only form under $280^{\circ} \mathrm{C}$. Moreover, low $\mathrm{H} 2 \mathrm{~S}$ concentrations within the fluids suggest a limited magmatic contribution to the heat source, i.e., a moderate venting temperature (Hodgkinson et al., 2015). These observations rule out the possibility of an initially high-temperature UMHS having cooled down. Therefore, it is possible to use the VDVF as a comparison with Rainbow and Lost City to fully explore the impact of temperature on serpentinization dynamics and on the magnetic signature of UMHSs.

By studying the RTP anomaly over the site and its surroundings, the relative concentration of magnetite within the stockwork zone can be inferred by comparison with that from Rainbow and Lost City. At first order, the magnetite magnetization is subject to the intensity of the magnetizing field, grain size, and domain state (Dunlop and Prévot, 1982; Cullity and Graham, 2009); however, serpentinization does not have any significant impact on the magnetic grain size (Oufi et al., 2002; Malvoisin et al., 2012). Moreover, on a first order, these three hydrothermal vent fields have comparable dimensions (e.g., Szitkar et al., 2014b, 2017); i.e., the main observed differences are likely to be dominated by variations in the magnetite concentrations within the host rocks (see the Data Repository).

In a first step, we estimated the average seafloor equivalent magnetization out of the hydrothermal area (Fig. DR1 in the Data Repository). This inversion was performed using the same parameters as for Rainbow and Lost City to ensure a proper comparison (Szitkar et al., 2014b, 2017; see also the Data Repository). Away from the vent field, equivalent magnetization reaches an average of $1.2 \mathrm{~A} / \mathrm{m}$. In the vicinity of the hydrothermal site, however, the equivalent magnetization peaks at $3 \mathrm{~A} / \mathrm{m}$ (Fig. DR2). This magnetization is higher than that observed at the 
Lost City site (2 A/m; Szitkar et al., 2017) but remains considerably weaker than that at Rainbow (30 A/m).

In order to precisely constrain the role of temperature, we compared the respective amounts of magnetite at these three sites (Fig. 3). The fluid temperature at the VDVF is up to $215^{\circ} \mathrm{C}$ (Hodgkinson et al., 2015), i.e., comparable to the critical temperature determined by Klein et al. (2014). Assuming this temperature remained constant over time, and given the similar dimensions of Lost City, VDVF, and Rainbow, it appears that the magnetite concentration does not follow a linear evolution with temperature, because such an evolution would lead to an observed magnetization of $4.5 \mathrm{~A} / \mathrm{m}$ at Rainbow, whereas the observed RTP anomaly at this last hydrothermal site suggests a magnetization of $\sim 30 \mathrm{~A} / \mathrm{m}$ (Fig. 3). Instead, the observed magnetization contrasts suggest that the magnetite concentration within the VDVF is 1.5 higher than that at Lost City but at least 10 times weaker than that at Rainbow. This observation is in accordance with the results from Klein et al. (2014), revealing that iron partitions preferentially into weakly magnetic brucite at temperatures under $200{ }^{\circ} \mathrm{C}$, whereas the partition into magnetite dominates above $200^{\circ} \mathrm{C}$. As the magnetization within the VDVF stockwork zone is slightly higher than within the Lost City plumbing system, we propose that the magnetite concentration increases slowly under $200^{\circ} \mathrm{C}$. When breaking the critical $\sim 200^{\circ} \mathrm{C}$ mark, this rise suddenly intensifies and results in a dramatic increase in magnetite production. Our results therefore underline the temperature dependence of serpentinization reaction products within the deep parts of UMHSs: Under $200{ }^{\circ} \mathrm{C}$, Fe-rich brucite dominates while magnetite production increases slowly with temperature. Beyond $200{ }^{\circ} \mathrm{C}$, the dynamics of the chemical reaction change and mainly produce magnetite, considerably increasing the site's magnetic signature (Fig. 3 ).

Magnetic data acquired from near-seafloor vehicles like the Autosub 6000, used at the VDVF, also allow the sub-seafloor geometry of the magnetizing source to be constrained. At the VDVF, the observed positive magnetic signature is slightly shifted by $\sim 100 \mathrm{~m}$ to the north compared to the location of the main, active hydrothermal mound (Fig. 2C). In this area, the data were collected at an altitude of $\sim 100 \mathrm{~m}$; i.e., the sources producing the dominating anomalies are mostly located within 100-200 m under the seafloor. Magnetic modeling using a $3 \mathrm{~A} / \mathrm{m}$ magnetized stockwork zone surrounded by a $1.2 \mathrm{~A} / \mathrm{m}$ magnetized seafloor allows precise contouring of the magnetic source geometry, which is seen to be inclined by $40^{\circ}$ to the north (Fig. 2; see the Data Repository). If the magnetization is caused by magnetite precipitation in the stockwork system, this suggests that the fluid-flow pathways responsible for the highertemperature precipitation of magnetite are not vertical but also follow a $40^{\circ}$ dip to the north. The cause of the inclined fluid path may reflect the orientation of faults in the vicinity of the VDVF (mostly striking north-south). The inclination may also reflect the domed structure of the OCC, with the VDVF located on the east-sloping, central axis of the domed structure. Buoyant fluids are known to be deflected by the geometry of the seafloor and migrate toward the center of bathymetric highs (e.g., Szitkar and Dyment, 2015). Alternatively, the decrease in temperature of the hydrothermal discharge and increase in age of the deposits toward the north, over a distance of $250 \mathrm{~m}$, at the VDVF (Hodgkinson et al., 2015) suggest that the inclination in fluid flow has evolved from a near-vertical ascent to its now-inclined state, possibly as a result of closure of the permeability of the plumbing system by precipitation of hydrothermal precipitates over time. The presence of the inclined fluid pathway beneath the VDVF also suggests the existence of a heat source deep within the structure of the OCC that is located to the north of the VDVF, consistent with the presence of a neovolcanic ridge that intersects the north side of the Mount Dent OCC, downslope from the VDVF. We suggest that intrusions, propagating southward from this neovolcanic ridge into the OCC, are the heat source for the VDVF, and fluids then ascend up north-south-striking fault planes toward the highest point of the OCC and emerge at the VDVF. 


\section{CONCLUSION}

High-resolution magnetic data reveal that the VDVF is associated with a stronger positive magnetization contrast than that observed at the lowtemperature UMHS Lost City; i.e., its stockwork zone hosts a slightly higher concentration of magnetite. Nevertheless, this limited additional amount of magnetite supports the need for a faster production rate above the critical $200{ }^{\circ} \mathrm{C}$ temperature to reach a magnetic signature comparable to that of high-temperature UMHS Rainbow. This study therefore confirms the fundamental role of temperature in the magnetite production within UMHS stockwork zones or plumbing systems: below $200^{\circ} \mathrm{C}$, UMHSs are associated with a weakly positive magnetic signature slowly intensifying when temperature rises. For venting sites associated with a temperature above $200^{\circ} \mathrm{C}$, the concentration of magnetite drastically increases and makes them easy to identify on deep-sea magnetic data sets. These results consequently refine the knowledge base concerning the magnetic footprint of hydrothermal systems and will facilitate discovery of hydrothermal sites, regardless of their geological and geophysical contexts, during future scientific cruises.

\section{ACKNOWLEDGMENTS}

We thank the captain and crew of RRS James Cook and the technical team of the autonomous underwater vehicle AutoSub 6000 for excellent work at sea. We especially thank Tim LeBas for processing the high-resolution bathymetric data used in this study. The Japan Agency for Marine-Earth Science and Technology (Jamstec; Yokosuka, Japan) supported this research. We also thank the reviewers for their highly appreciated suggestions. 


\section{FIGURES}

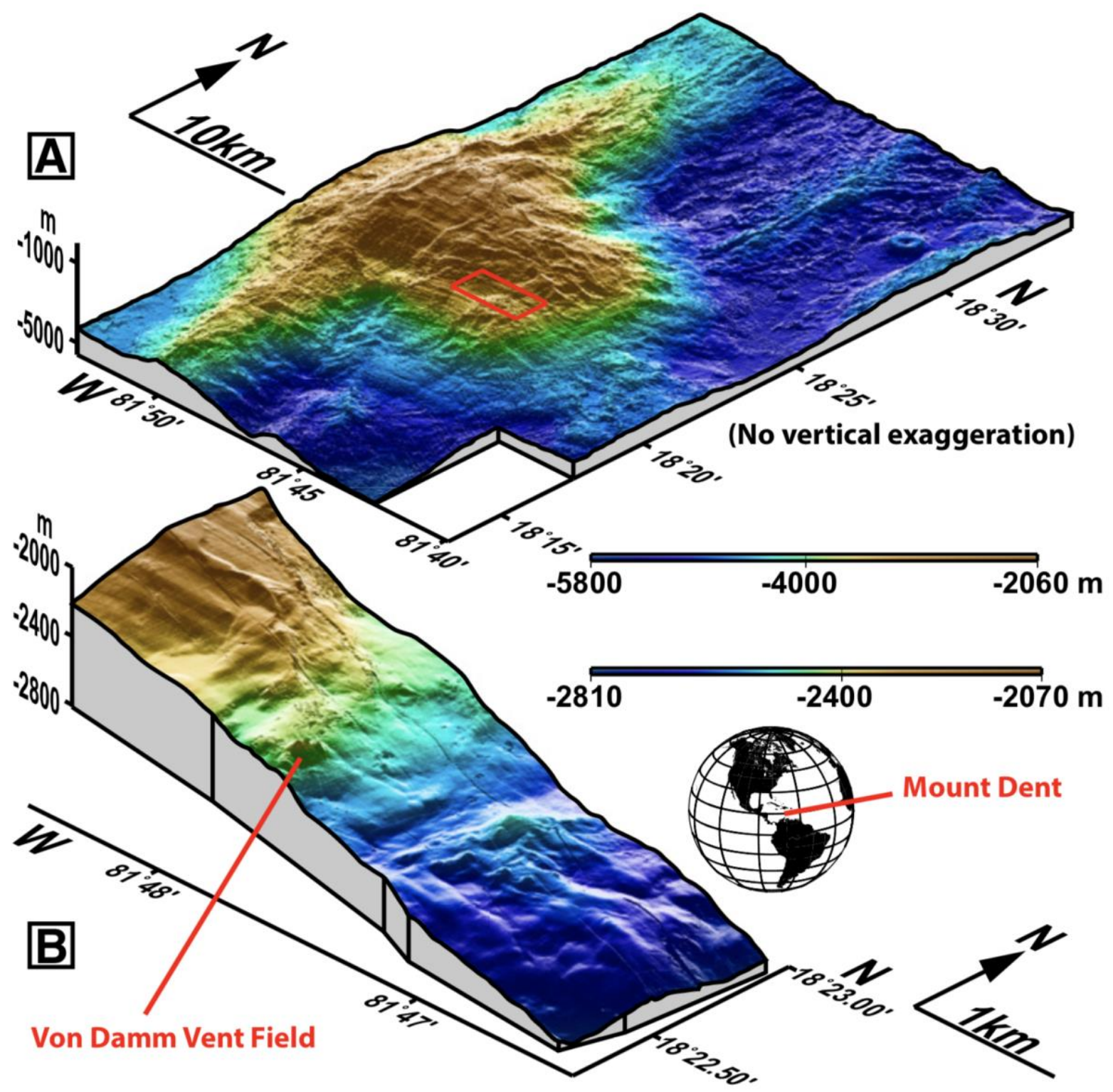

Figure 1. A: Regional bathymetry of Mount Dent oceanic core com-plex, Mid-Cayman spreading center, Caribbean Sea. Typical dome-like structure and east-west corrugations are clearly visible. B: High-res- olution bathymetry of Von Damm Vent Field area, Mid-Atlantic Ridge. Hydrothermal site and associated prominent mound overlook smooth seafloor slope in surrounding area. 


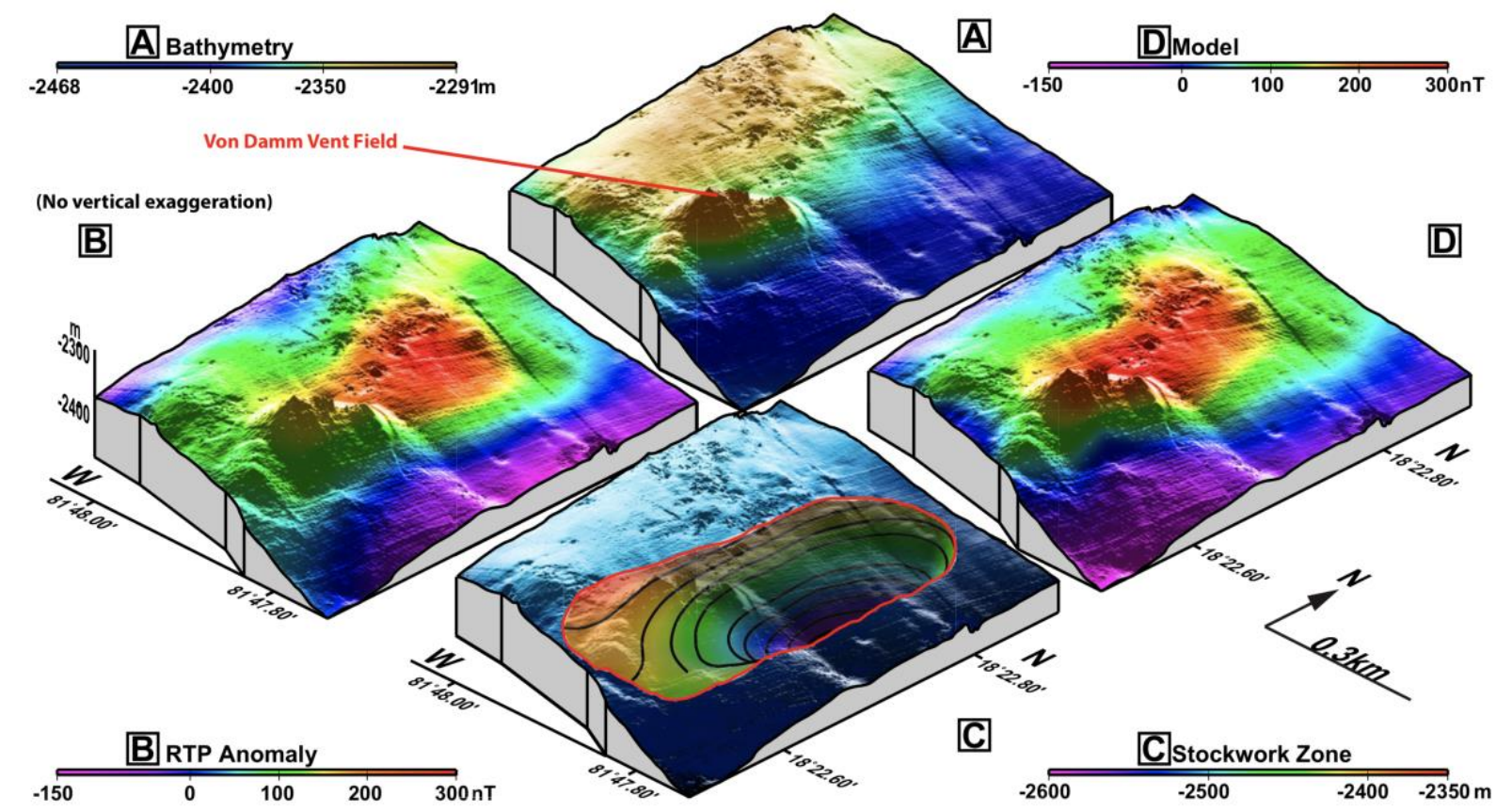

Figure 2. A: High-resolution bathymetry focusing on hydrothermal site. Mound is on average $200 \times 300 \mathrm{~m}$ in area and $50 \mathrm{~m}$ high. B: Reduced- to-pole (RTP) magnetic anomaly computed from equivalent magnetization deduced from Honsho et al. (2012) inversion. Positive anomaly is located 100 m north of mound (Fig. DR2 [see text footnote 1]), revealing existence of an inclined fluid pathway at depth. C: Proposed contours of stockwork geometry. Average magnetization within this stockwork zone is $3 \mathrm{~A} / \mathrm{m}$, surrounded by a $1.2 \mathrm{~A} / \mathrm{m}$ magnetized seafloor. D: Magnetic model estimated using stockwork geometry from $C$ and a $3 \mathrm{~A} / \mathrm{m}$ magnetized stockwork zone.

\section{REFERENCES}

Ballard, R.D., et al., 1979, Geological and geophysical investigation of the MidCayman Rise spreading center: Initial results and observations, in Talwani, M., Harrison, C.G., and Hayes, D.E., eds., Deep Drilling Results in the Atlantic Ocean: Ocean Crust: American Geophysical Union Maurice Ewing Series Volume 2, p. 66-95, https://doi.org/10.1029/ME002p0066.

Cannat, M., 1993, Emplacement of mantle rocks in the seafloor at mid-ocean ridges: Journal of Geophysical Research, v. 98, p. 4163-4172, https://doi .org/10.1029/92JB02221.

Connelly, D.P., et al., 2012a, Hydrothermal vent fields and chemosynthetic biota on the world's deepest seafloor spreading centre: Nature Communications, v. 3, 620, https://doi.org/10.1038/ncomms1636. Connelly, D.P., et al., 2012b, RRS James Cook Cruise 44, 25 Mar-22 Apr 2010, Trinidad to Jamaica: Hydrothermal activity and deep-ocean biology of the Mid-Cayman Rise: Southampton, UK, National Oceanography Centre Southampton, National Oceanography Centre Cruise Report 17, 100 p.

Corliss, J.B., et al., 1979, Submarine thermal springs on the Galapagos Rift: Science, v. 203, p. 1073-1083, https://doi.org/10.1126/science.203.4385.1073. 
Cullity, B.D., and Graham, C.D., 2009, Introduction to Magnetic Materials: Hoboken, New Jersey, John Wiley \& Sons, Inc., 568 p.

Dunlop, D.J., and Prévot, M., 1982, Magnetic properties and opaque mineralogy of drilled submarine intrusive rocks: Geophysical Journal of the Royal Astronomical Society, v. 69, p. 763-802, https://doi.org/10.1111/j.1365-246X.1982.tb02774.x.

Escartín, J., Smith, D.K., Cann, J., Schouten, H., Langmuir, C.H., and Escrig, S., 2008, Central role of detachment faults in accretion of slow-spreading oceanic lithosphere: Nature, v. 455, p. 790-794, dhttps://doi.org/10.1038 /nature07333.

Früh-Green, G.L., Plas, A., and Lecuyer, C., 1996, Petrologic and stable isotopic constraints on hydrothermal alteration and serpentinization of the EPR shallow mantle at Hess Deep, Site 895, in Mevel, C., et al., Proceedings of the Ocean Drilling Program, Scientific Results, Volume 147: College Station, Texas, Ocean Drilling Program, p. 109-163.

Früh-Green, G.L., Connolly, J.A.D., Plas, A., Kelly, D.S., and Gobéty, B., 2004, Serpentinization of oceanic peridotites: Implications for geochemical cycles and biological activity, in Wilcock, W.S.D., et al., eds., The Subseafloor Biosphere at Mid-Ocean Ridges: American Geophysical Union Geophysical Monograph 144, p. 119-136, https://doi.org/10.1029/144GM08.

Hayman, N.W., Grindlay, N.R., Perfit, M.R., Mann, P., Leroy, S., and de Lépinay, B.M., 2011, Oceanic core complex development at the ultraslow spreading Mid-Cayman spreading centre: Geochemistry Geophysics Geosystems, v. 12, Q0AG02, https://doi.org/10.1029/2010GC003240.

Hodgkinson, M.R.R., Webber, A.P., Roberts, S., Mills, R.A., Connelly, D.P., and Murton, B.J., 2015, Talc-dominated seafloor deposits reveal a new class of hydrothermal system: Nature Communications, v. 6, 10150, https://doi.org /10.1038/ncomms10150.

Honsho, C., Dyment, J., Tamaki, K., Ravilly, M., Horen, H., and Gente, P., 2009, Magnetic structure of a slow-spreading ridge segment: Insight from nearbottom magnetic measurement onboard a submersible: Journal of Geophysical Research, v. 114, B05101, https://doi.org/10.1029/2008JB005915.

Honsho, C., Ura, T., and Tamaki, K., 2012, The inversion of deep-sea magnetic anomalies using Akaike's Bayesian information criterion: Journal of Geophysical Research, v. 117, B01105, https://doi.org/10.1029/2011JB008611.

Honsho, C., Ura, T., and Kim, K., 2013, Deep-sea magnetic vector anomalies over the Hakurei hydrothermal field and the Bayonnaise knoll caldera, IzuOgasawara Arc, Japan: Journal of Geophysical Research, v. 118, p. 5147-5164, https://doi.org/10.1002/jgrb.50382.

Isezaki, N., 1986, A new shipboard three-component magnetometer: Geophysics, v. 51, p. 1992-1998, https://doi.org/10.1190/1.1442054.

Kelley, D.S., et al., 2001, An off-axis hydrothermal vent field near the Mid-Atlantic Ridge at $30^{\circ} \mathrm{N}$ : Nature, v. 412, p. 145-149, https://doi.org/10.1038/35084000. Klein, F., Bach, W., Humphris, S.E., Kahl, W.-A., Jöns, N., Moskowitz, B., and Berquó, T.S., 2014, Magnetite in seafloor serpentinite-Some like it hot: 
Geology, v. 42, p. 135-138, https://doi.org/10.1130/G35068.1. Malvoisin, B., Brunet, F., Carlut, J., Rouméjon, S., and Cannat, M., 2012, Serpentinization of oceanic peridotites: 2. Kinetics and processes of San Carlos olivine hydrothermal alteration: Journal of Geophysical Research, v. 117, B04102, https://doi.org/10.1029/2011JB008842.

Oufi, O., Cannat, M., and Horen, H., 2002, Magnetic properties of variably serpentinized abyssal peridotites: Journal of Geophysical Research, v. 107, p. 3-19, https://doi.org/10.1029/2001JB000549.

Rona, P.A., Devey, C.W., Dyment, J., and Murton, B.J., eds., 2010, Diversity of Hydrothermal Systems on Slow Spreading Ocean Ridges: American Geophysical Union Geophysical Monograph 188, 440 p., https://doi.org/10.1029/GM188.

Szitkar, F., and Dyment, J., 2015, Near-seafloor magnetics reveal tectonic rotation and deep structure at TAG (Trans-Atlantic Geotraverse) hydrothermal site (Mid-Atlantic Ridge, $26^{\circ} \mathrm{N}$ ): Geology, v. 43, p. 87-90, https://doi.org /10.1130/G36086.1.

Szitkar, F., Dyment, J., Fouquet, Y., and Choi, Y., 2014a, What causes low magnetization at basalt-hosted hydrothermal sites? Insights from inactive site Krasnov (MAR, $\left.16^{\circ} 38^{\prime} \mathrm{N}\right)$ : Geochemistry Geophysics Geosystems, v. 15, p. 1441-1451, https://doi.org/10.1002/2014GC005284.

Szitkar, F., Dyment, J., Honsho, C., and Horen, H., 2014b, The magnetic signature of ultramafic-hosted hydrothermal sites: Geology, v. 42, p. 715-718, https:// doi.org/10.1130/G35729.1.

Szitkar, F., Tivey, M.A., Kelley, D.S., Karson, J.A., Früh-Green, G.L., and Denny, A.R., 2017, Magnetic exploration of a low-temperature ultramafic-hosted hydrothermal site (Lost City, $30^{\circ} \mathrm{N}$, MAR): Earth and Planetary Science Letters, v. 461, p. 40-45, https://doi.org/10.1016/j.epsl.2016.12.033.

ten Brink, U.S., Coleman, D.F., and Dillon, W.P., 2002, Asymmetric crustal thickness across Cayman spreading center and transitional crust in Cayman Trough from gravity: Marine and Petroleum Geology, v. 19, p. 971-987, https://doi.org/10.1016/S0264-8172(02)00132-0.

Tivey, M.A., Rona, P.A., and Schouten, H., 1993, Reduced crustal magnetization beneath the active sulfide mound, TAG hydrothermal field, Mid-Atlantic Ridge, at $26^{\circ} \mathrm{N}$ : Earth and Planetary Science Letters, v. 115, p. 101-115, https://doi .org/10.1016/0012-821X(93)90216-V.

Tucholke, B.E., Lin, J., and Kleinrock, M.C., 1998, Megamullions and mullions structure defining oceanographic metamorphic core complexes on the MidAtlantic Ridge: Journal of Geophysical Research, v. 103, p. 9857-9866, https:// 